\title{
The Impact of Class Actions on Rule 10b-5
}

Securities law literature largely ignores the role of the class action device $^{1}$ in the recent expansion of liability under section $10(\mathrm{~b})$ of the 1934 Securities Exchange Act and SEG rule 10b-5. ${ }^{2}$ Indeed, both courts and commentators maintain a dichotomy between the "substantive" considerations of $10 \mathrm{~b}-5$ and the "procedural" considerations of rule 23. Commentators, of course, argue that increased use of class actions in the $10 \mathrm{~b}-5$ setting is likely to enhance the effectiveness of the rule in forcing disclosure. ${ }^{4}$ But these observations do not depend on the possibility that the use of class actions will prompt changes in the substantive requirements of a 10b-5 cause of action. They assume instead that no change in substantive law will result from the introduction of the class action device. $^{5}$

This comment examines, in the context of disclosure rules, the proposition that any judgment of the propriety of maintenance of a class action necessarily entails a definition of the elements of a cause of action. If this necessity is not explicitly recognized, the unfortunate consequence may be a failure to consider fully the merits of a change in

1 FED. R. Crv, P. 23 [hereinafter cited as rule 23].

2 Securities Exchange Act of $1934 \S 10(\mathrm{~b}), 15$ U.S.C. $\S 78 \mathrm{j}(\mathrm{b})$ (1964); SEC Rule 10b-5, 17 C.F.R. \& $240.10 \mathrm{~b}-5$ (1970) [hereinafter cited as 10b-5].

3 For a thorough procedural analysis of rule 23 with no attention to substantive law considerations, see Kaplan, Continuing Work of the Civil Committee: 1966 Amendments of the Federal Rules of Civil Procedure (I), 81 HARv. L. REv. 356 (1967), and Wright, Class Actions, 47 F.R.D. 169 (1969). Similarly, commentaries on $10 \mathrm{~b}-5$ give little consideration to the effects of class actions. See A. Bromberg, Securmes LAw: Fraud-SEC Rule 10b-5 (1968) [hereinafter cited as BRomberg], and $6 \mathrm{~L}$. LOSs, SEcurmtes Regulation 3940. 69 (3d ed. Supp. 1969). Commentators examining 10b-5 class actions have concentrated exclusively on their procedural dfficulties. See Bernfeld, Class Actions and Federal Securities Laws, 55 CoRnell L. REv. 78 (1969); Leader, Threshold Prerequisites to Securities Fraud Class Actions, 48 TEXAs L. REv. 417 (1970); Comment, Class Action Treatment of Securities Fraud Suits Under the Revised Rule 23, 36 GEo. WASH. L. REv. 1150 (1968). But see Note, Federal Rules of Civil Procedure: Rule 23, The Class Action Device and Its Utilization, 22 U. FLA. L. REv. 681, 644 (1970).

4 See, e.g., 3 L. Loss, Securities Regulation 1819 (2d ed. 1961).

- The "Act Empowering the Supreme Court of the United States to Prescribe Rules" provides in part: "Said rules shall neither abridge, enlarge nor modify the substantive rights of any litigant." The Act of June 1984, 28 U.S.C. $§ 2072$ (1964), as amended 28 U.S.C. \$ 2072 (Supp. IV, 1969). Also, see Advisory Committee Note, Proposed Rules of Civil Procedure, 39 F.R.D. 98, 103 (1966). 
substantive requirements. In the securities law field, where pressures for the maintenance of class actions are particularly strong, the dangers of ill-considered change of substantive law are acute and counsel careful examination of the implications of expansion of $10 \mathrm{~b}-5$ liability.

\section{The Operational Effects of the Class Agtion Device}

Hall v. Coburn Corp., ${ }^{\mathbf{B}}$ a consumer class action in the New York Court of Appeals, illustrates the relationship between class actions and changes in substantive law. A large number of buyers entered into retail installment contracts for carpeting with different sellers. Suing as a class, the buyers alleged that material parts of the contracts were printed in smaller than eight-point type, the minimum size required by statute. The action was brought against a finance company, the assignee and printer of the contracts. Each plaintiff sought recovery of the credit service charge. ${ }^{7}$

Plaintiffs' decision to base the claim on print size, a theory of statutory liability per se, probably was motivated by two considerations. First, if they had brought the action against all sellers on the terms of the contracts, on a theory of unconscionability or common law fraud, they would have been subject to the defense that the question presented was not "one of a common or general interest of many persons." Each contract had different terms and contractual parties. Second, the credit charge in the contracts was authorized by New York law. ${ }^{9}$

Affirming the trial court dismissal of the case, the court of appeals interpreted prior class action case law as requiring "something more" than identical facts and found that class actions were permissible only in those cases involving "closely associated relationships growing out of trust, partnership or joint venture, and ownership of corporate stock."10 Moreover, the court rejected the theory based on the print size of the contract type, admittedly a technical statutory violation, finding that it did not strike at the "real evil" of retail credit buying-the amount of credit service charge. ${ }^{11}$ Finally, the court felt there were other remedies available to the class, such as administrative action by the newly created State Consumer Protection Board. ${ }^{12}$

626 N.Y.2d 396, 259 N.E.2d 720, 311 N.Y.S.2d 281 (1970).

7 N.Y. Pers. Prop. LAw §§ 402, 414(2).

8 N.Y. CIV. Prac. LAW § I005(a) reads in relevant part: "When allowed. Where the question is one of a common or general interest of many persons or where the persons who might be made parties are very numerous ... one or more may sue or defend for the benefit of all."

9 N.Y. Pers. Prop. Law \& 404.

1026 N.Y.2d at 402,259 N.E.2d at 722, 311 N.Y.S.2d at 284.

11 Id. at $402-03,259$ N.E.2d at 723,311 N.Y.S.2d at 285.

12 N.Y. EXEC. LAW § 553. 
The result in Hall does not seem compelled by prior class action case law. The court, instead of imposing an additional requirement that the case involve trust, partnership or joint venture, or ownership of stock, could easily have held that class actions were available where there were identical facts. ${ }^{13}$ Further, it is clear that individuals have successfully maintained actions under the same statutory liability theory advanced in Hall. $^{14}$ As for the alternate remedies, the statute expressly authorizes a private right of action, ${ }^{15}$ and one of the powers of the State Consumer Protection Board is to cooperate with and assist consumer class actions in proper cases. ${ }^{16}$ What then explains the result?

The court was evidently unwilling to allow a "technicality" to be used in a class action where it would produce large damages and have the effect of broadly undermining existing legislative policy regarding legitimate credit charges. Although identical facts had been pleadedthe print size was identical and common to all of the contracts-the court considered these facts, when alleged in a class action, an improper basis for liability.

The Hall analysis can be compared profitably with the approach of the Sixth Circuit in Mader v. Armel. ${ }^{17}$ There, owners of stock in Certi-

13 The court might have relied on Guffanti v. National Surety Co., 196 N.Y. 452, 90 N.E. 74 (1909) (Crane, J.), where a class action on behalf of depositors for foreign remittance was allowed against the surety of a defaulting bondholder. Judge Crane relied heavily on POMERoy, EQUiTY JURISPRUDENCE $\$ 269$ (3d ed. 1905), quoting as follows:

Under the greatest diversity of circumstances, and the greatest variety of claims arising from unauthorized public acts, private tortious acts, invasion of property rights, violation of contract obligations, and notwithstanding the positive denials by some American courts, the weight of authority is simply overwhelming that the jurisdiction may and should be exercised either on behalf of a numerous body, although there is no "common title" nor "community of right" or of "interest in the subject matter" among these individuals but where there is and because there is merely a community of interest among them in the question of law and fact involved in the general controversy ....

196 N.Y. at 458, 90 N.E. at 176 (emphasis added). In Lichtyger v. Franchard Corp., 18 N.Y.2d 528, 534, 223 N.E.2d 869, 873, 377 N.Y.S.2d 277, 382 (1966) (Fuld, J.) (class action by limited partners against general partners to recover damages for waste and mismanagement), the court relied on Guffanti, among other cases, in characterizing the test as one of "common or general interest." The Hall test, limiting class actions to certain enumerated situations, is difficult to justify on the assumption that only these situations provide for a "common or general interest." Indeed, the "common or general interest" may have been stronger in Hall than in Lichtyger. Compare Lichtyger, 18 N.Y.2d at 536 n.2, 223 N.E.2d at 874,377 N.Y.S.2d at 384, with Korn v. Franchard Corp., CCH FED. SEC. L. REP. ๆ 92,845 (S.D.N.X. 1970).

14 Ben Constr. Corp. v. Rivers, 29 App. Div. 2d 1048, 289 N.Y.S.2d 866 (1968); Gramatan Co. v. Jones, 23 App. Div. 2d 940, 260 N.Y.S.2d 54 (1965) (by implication); Ben Constr. Corp. v. Snushall, 44 Misc. 2d 878, 880-81, 254 N.Y.S.2d 948, 950 (Sup. Ct. 1964).

15 N.Y. Pers. Prop. LAw \& 414(2) expressly grants a buyer a private right of action against any person who fails to comply with $\S 404$ which fixes the print size required.

16 N.Y. ExEc. LAW § 553(3)(c).

17402 F.2d 158 (6th Cir. 1968), cert. denied, 394 U.S. 930 (1969). 
fied Mortgage Corporation, the target of a successful merger, brought a $10 \mathrm{~b}-5$ class action against the officers and directors of Certified to recover the decrease in the value of their stock allegedly resulting from the merger. Plaintiffs claimed that the merger had been accomplished by misrepresentations and omissions of material facts in proxy statements.

The district judge originally ordered ${ }^{18}$ the case to proceed as a class suit as required by rule 23.19 Later, however, he found that the merger did not involve a sale within the meaning of rule 10b-5 and granted defendants' motions to dismiss and for summary judgment. In ordering dismissal, the court indicated that if the case had proceeded to trial the ruling maintaining the class action would have been vacated, in part, because each member of plaintiff class would have had to prove his reliance on the alleged misrepresentations.

The Court of Appeals for the Sixth Circuit reversed and remanded in a two-part opinion. First, the court held that a merger does constitute a sale within the meaning of rule 10b-5. Second, it held that the suit had properly been maintained as a class action.

Defendants' objection to the propriety of the class action was that questions of fact and law were not common to the class. ${ }^{20}$ They contended that not all of the shareholders might have relied on the misrepresentations, suggesting that some might have signed the proxies without reading the proxy statements, while others might not even have signed them.

The court of appeals responded to this argument by questioning the reliance requirement itself. It distinguished the case relied upon by the district court, List v. Fashion Park, Inc., ${ }^{21}$ stating that " $L$ ist was not a class action suit. It involved only one plaintiff." 22 It went on to decide that actual reliance on the misrepresentation was not required. It was sufficient that plaintiffs presumably had relied on the honesty and fair dealing of the company when they purchased their shares. ${ }^{23}$ Thus, the court dispensed with defendants' class action objections by presuming, as a matter of law, that the element of the claim that might give rise to uncommon questions was present.

In both Hall and Mader the focal point was the necessity for "com-

$18 \mathrm{Id}$. at $159,161$.

19 Fed. R. Crv. P. 23(a).

20 FED. R. Crv. P. $23(\mathrm{~b})(3)$ is the section of rule 23 under which $10 \mathrm{~b}-5$ actions are generally brought. See generally 3B MOORE's FEDERAL PRACTICE If 23.45[2] (2d ed. 1969). See Leader, supra note 3 , at 418 . Before a suit can be maintained on a class basis, rule $23(\mathrm{~b})(3)$ requires that the court find "that the questions of law or fact common to the members of the class predominate over any questions affecting only individual members . . .."

21340 F.2d 457 (2d Cir.), cert. denied, 382 U.S. 811 (1965).

22402 F.2d at 162.

23 Id. at 162-63. 
mon questions." In Hall the court was unwilling to allow a class action even though the strict liability theory presented only common questions. The court felt that such a theory would undercut legislative policy. In Mader the court found common questions by changing the List reliance requirement.

Both cases point out how courts can maintain different requirements for substantive causes of action in individual and class suits. Hall does not state that a strict liability theory would be unavailable in an individual action. It is the consequences of allowing the theory in a class action which bother the court. In Mader the court frankly states that the List requirement may be good law in individual actions but is not required in class actions.

However, the analytical approach in the two cases differs substantially. The Hall court's decision not to allow a class action is based on the court's judgment on the merits of plaintiffs' claim. The existence of a valid cause of action and a valid class action pose the same question for the court. In Mader, however, the issues are viewed separately. Since the court perceives itself as making a "procedural" ruling on the propriety of the class action, it seems not to appreciate fully the change it is making in the reliance requirement. Thus, it does not discuss the appropriateness of the change. ${ }^{24}$

More fundamentally, these two cases reflect different responses to the pressures of class actions. Although the Hall court recognized that a wrong had been suffered by a large class of buyers, it considered the substantive effects of maintenance of a class action, identified its policy preference, and disposed of the class action accordingly. ${ }^{25}$ The Mader court, on the other hand, responded to the pressures of a large class of defrauded investors by asking the procedural question about common questions and eliminating an element of $10 \mathrm{~b}-5$ liability that threatened the class suit. It is the response of Mader, rather than that of Hall, that typifies the course of development in the securities law area.

\section{The Class Action Gatalyst in 10b-5 Expansion}

If class actions exert peculiar effects on substantive law, and these effects have not yet been recognized, one would expect to find different

24 The different approaches of the two courts are explained, in part, by the federal court practice of separating the motion to maintain or dismiss a class action from the motion to dismiss on the merits, 2 BARRoN \& Holmzorf § 562, at 89 (Wright ed. Supp. 1969); Frankel, Some Preliminary Observations Concerning Civil Rule 23, 43 F.R.D. 39, 40-42 (1968); Note, Interlocutory Appeal From Orders Striking Class Action Allegations, 70 ColUM. L. REv. 1292 (1970). Even though the Mader court had both issues before it on appeal, an unusual event in a $10 \mathrm{~b}-5$ class action, its opinion treats the two issues separately as if their resolution were independent.

2526 N.Y.2d at 404,259 N.E.2d at 723, 311 N.Y.S.2d at 286. 
standards in individual and class actions under $10 \mathrm{~b}-5$. The necessary elements of a valid $10 \mathrm{~b}-5$ individual claim are readily discerned. ${ }^{26} \mathrm{Ex}$ amination of the status of these same elements in class actions should reveal any variations and thus the role of the class action device in transforming the elements of a claim.

\section{A. Individual Actions Under 10b-5}

Reliance is a generally acknowledged element of a $10 \mathrm{~b}-5$ individual claim, at least since List v. Fashion Park, Inc. ${ }^{27}$ In List, plaintiff-seller of Fashion Park stock alleged a material non-disclosure of an impending merger and of his buyer's position as a director of Fashion Park. He claimed the difference between his selling price and the price later offered to minority shareholders of Fashion Park as part of the merger. The Second Circuit affirmed the district court's dismissal of the complaint and upheld its finding that plaintiff would have sold his stock even if he had known that an insider was one of the buyers. As with causation in tort, the court remarked, reliance is a necessary element of a 10b-5 claim. The appropriate test is "whether the plaintiff would have been influenced to act differently than he did act if the defendant had disclosed to him the undisclosed fact." 28 Later cases approve the List doctrine. ${ }^{29}$ The reliance requirement seems to be grounded in a notion of fairness-defendants should not be liable for injuries they did not

26 There is an enormous literature on all aspects of the substantive requirements for individual actions under 10b-5. A comprehensive bibliography is available in BROMBERG, supra note 3, at app. h. Of particular value are $W$. PAINTER, FEDERAI REgulation of INSIDER TRADING (1968); Fleischer, "Federal Corporation Law": An Assessment, 78 HARv. L. REv. 1146 (1965); Ruder, Texas Gulf Sulphur-The Second Round: Privity and State of Mind in Rule 10b.5 Purchase and Sale Cases, 63 Nw. U.L. REv. 423 (1968). The policy premises of recent developments are best discussed in Cohen, "Truth in Securities" Revisited, 79 HARv. L. REv. 1340 (1966). The best up-to-date survey of the cases is found in De Lancey, Rule 10b-5-A Recent Profile, 25 Bus. LAw. 1355 (1970).

27340 F.2d 457 (2d Cir.), cert. denied, 382 U.S. 811 (1965). See R. JENnings \& H. Marsh, Jr., Securities Regulation Cases and Materials 909-10 (2d ed. 1968). Compate 6 L. Loss, SECURITIES REGULATION 3876 (3d ed. Supp. 1969) (reliance has generally been required), with 3 L. Loss, SEcurities Regulation 1766 (2d ed. 1961) (reliance may be little more than a formal requirement).

28340 F.2d at 462. The Second Circuit, relying on REstatement of TorTs § 546 (1938), stated: "Thus to the requirement that the individual plaintiff must have acted upon the fact misrepresented, is added the parallel requirement that a reasonable man would also have acted upon the fact misrepresented." (Emphasis in original.)

29 Chasins v. Smith, Barney \& Co., CCH FED. SEc. L. REP. I 92,712 (2d Cir. 1970); Reyos v. United States, 431 F.2d 1337, 1348 (10th Cir. 1970); Gilbert v. Nixon, 429 F.2d 348, 356 \& n.16, 357 \& n.18 (10th Cir. 1970); City Nat'l Bank v. Vanderboom, 422 F.2d 221, 230-31 (8th Cir.), cert. denied, 91 S. Ct. 47 (1970); Northwest Paper Corp. v. Thompson, 421 F.2d 137 (9th Cir. 1969); Britt v. Cyril Bath Co., 417 F.2d 433, 436 (6th Cir. 1969); Myzel v. Fields, 386 F.2d 718, 736 (8th Cir.), cert. denied, 390 U.S. 951 (1967); Rogen v. Ilikon Corp., 
cause $^{30}$-and on a judgment that the Securities Exchange Act seeks to protect only those whose conduct would have been affected by the availability of accurate information.

The affirmative defense of in pari delicto, like reliance, can be dispositive of a $10 \mathrm{~b}-5$ action, and a comparison of its status in individual and class actions is useful. ${ }^{31}$ The defense prevents recovery by the plaintiff who thought he was acting on the basis of inside information. It reflects a reluctance to use the Securities Exchange Act to compensate those who intended to violate its provisions.

In the leading case of Kuehnert $v$. Texstar Corp. ${ }^{32}$ the Fifth Circuit characterized the plaintiff as a dupe who believed he was a tippee and who intended to take wrongful advantage of the tip. The court dismissed the suit, even though the effect of dismissal was to insulate the tipper-defendant from liability for a material non-disclosure. The court reasoned that to do otherwise would give the tippee an enforceable warranty that secret information is true. ${ }^{33}$

Judge Godbold, dissenting, felt that the interest in securities law enforcement overrode the danger that plaintiff would get a windfall recovery. He also identified an inherent difficulty in administering the in pari delicto doctrine: "There are problems of deciding when a party's 'badness' is sufficient to warrant the application of in pari delicto which makes it almost impossible to create an orderly and consistent body of law on the subject."34

Transactions with broker-dealers came before a court in Wohl $v$. Blair, ${ }^{35}$ where the issue was whether a person who buys stock on the basis of inside information from his broker may recover against the broker when it turns out that the "inside information" was untrue. The court adopted the priorities of the Kuehnert majority and refused to strike the affirmative defense. A new consideration appeared in the court's reasoning: "[I]t may well be that much of the excessive and inflationary speculation in securities is attributable to customers seeking information which they are not entitled to have unless and until it is

361 F.2d 260, 266 (1st Cir. 1966); Robinson v. Cupples Container Co., 316 F. Supp. 1362, 1366 (N.D. Cal. 1970); Phillips v. Reynolds \& Co., 294 F. Supp. 1249, 1256 (E.D. Pa. 1969).

30 Painter, Inside Information: Growing Pains for the Development of Federal Corporation Law Under Rule 10b-5, 65 CoLUM. L. REv. 1361, 1370-71 (1965).

31 For discussion of the defense, see Note, In Pari Delicto and Unclean Hands As Defenses to Private Suit Under SEC Rule 10b-5, 30 MD. L. REv. 75 (1970); Comment, Plaintiff's Conduct as a Bar to Recovery Under the Securities Acts: In Pari Delicto, 48 TEXAS L. REv. 181 (1969).

32412 F.2d 700 (5th Cir. 1969).

$33 \mathrm{Id}$. at 705.

$341 d$. at 706 \& $\mathrm{n} .3$ (Godbold, J., dissenting).

35 S0 F.R.D. 89 (1970). 
freely available to all." ${ }^{36}$ Speculators, therefore, are particularly subject to this "badness" test under the in pari delicto doctrine. ${ }^{37}$

The recent Second Circuit decision in Pearlstein v. Scudder o German $^{38}$ adopts a contrary position with regard to a broker violation of Regulation $T$, which proscribes margin requirements. ${ }^{39}$ The defendant's claim, that Pearlstein knew that the requirements were being violated, was not a bar to recovery. The majority did not rule out, however, a bar to plaintiff's recovery when contributory fault goes beyond knowledge of the margin requirements to concealment or misstatement of material facts. ${ }^{40}$

Another major element of liability in individual $10 \mathrm{~b}-5$ actions is the materiality of the misrepresentation or omission. This requirement is explicit in the rule. ${ }^{41}$ In SEC v. Texas Gulf Sulphur Co..$^{42}$ the Second Circuit restated the definition of materiality it had formulated in List: "The basic test of materiality ... is whether a reasonable man would attach importance [to the omitted or misrepresented fact] ... in determining his choice of action in the transaction in question.' . . . This, of course, encompasses any fact '. . which in reasonable and objective contemplation might affect the value of the corporation's stock or securities ..." "43 This test focuses on a particular fact at a particular point in time. Materiality ". . . will depend at any given time upon a balancing of both the indicated probability that the event will occur and the anticipated magnitude of the event in light of the totality of the company activity." 44

The last element of liability is the purchase and sale requirement deriving from the limitation in section $10(b)$ that actionable fraud be "in connection with the purchase or sale of any security." 45 The leading

30 Id. at 93.

37 See Tracy \& MacChesney, The Securities Exchange Act of 1934, 32 Mrct. L. REv. 1025, 1034 (1934).

38429 F.2d 1136, 1141 (2d Cir. 1970), petition for cert. filed, 39 U.S.L.W. 3239 (U.S. Dec. $12,1970)$ (No. 1000). But see Friendly, J., dissenting, id. at 1145.

3912 C.F.R. § 220.4(c)(2) promulgated pursuant to 15 U.S.C. $\$ 78 g(a)$ (1964). This was joined with another count under $\S 7$ of the Securities Exchange Act of 1934, 15 U.S.C. $\S 78 \mathrm{~g}(\mathrm{c})$ (1964). Both were held actionable.

40429 F.2d at $1142-43 \& \mathrm{nn} .9 \& 10$.

4117 C.F.R. 240.10b-5(b): "[It shall be unlawful] [t]o make any untrue statement of a material fact or to omit to state a material fact necessary in order to make the statements made, in the light of the circumstances under which they were made, not misleading ...." 42401 F.2d 833 (2d Cir. 1968), cert. denied, 394 U.S. 976 (1969), on remand, SEC v. Texas Gulf Sulphur Go., 312 F. Supp. 77 (S.D.N.Y. 1970). See R. JEnnincs \& H. Marsh, JR., supra note 27 , at $909-11$.

43401 F.2d at 849 .

44 Id.

4515 U.S.C. \& 78j(b) (1964). 
judicial statement of the requirement is Birnbaum v. Newport Steel Corp.,$^{46}$ a derivative action in which the minority shareholders of Newport, a target company in a merger, sued the directors of both Newport and Wilport, the acquiring company. The plaintiffs alleged a sale of stock at a premium by Newport directors to Wilport, misrepresentations in letters sent to Newport shareholders explaining the acceptance of the Wilport bid, and the rejection of an alternate offer by a third company. The court held that since the minority shareholders had neither purchased nor sold securities in connection with the alleged misrepresentations they were not protected by $10 \mathrm{~b}-5 .{ }^{47}$

\section{B. Class Actions and 10b-5: The Erosion of Subjective Inquiry}

Reliance, in pari delicto, materiality and purchase and sale take on a different cast in class actions. At least since the 1966 amendment of rule 23 of the Federal Rules of Civil Procedure, if a class action is to be maintained, these elements of substantive liability must be funneled through rule 23's requirement that "questions ... common to the members of the class predominate...." Given the considerable pressure in securities law to adopt and foster class actions, there is a tendency, after viewing the elements of a $10 \mathrm{~b}-5$ claim solely in terms of the common questions proscription, to restrict the operation of any element that would frustrate commonality and fragment or prevent recovery by the class. This section examines the operation and effect of this process.

1. Reliance. The most common target of a non-common questions defense is reliance; defendant simply claims that some members of the class relied and some did not. Defendant will usually point out a particular non-relying member of the plaintiff class-often but not always the plaintiff-representative-to substantiate his point about reliance differences. ${ }^{48}$

In the preponderance of cases this non-common questions defense has not been successful. The result of failure to sustain the defense has been the near elimination of reliance as an element in class actions. However, few courts explicitly reject the defense with a statement that reliance is not required. They follow more circuitous paths to this end.

A common device is to postpone the reliance inquiry and treat reli-

46193 F.2d 461 (2d Cir.), cert. denied, 343 U.S. 956 (1952).

47 It was once thought that this requirement was in demise. E.g., Lowenfels, The Demise of the Birnbaum Doctrine: A New Era for Rule 10b-5, 54 VA. L. REv. 268 (1968). However: "Bloody but unbowed, Birnbaum still stands." Rekant v. Desser, 425 F.2d 872, 877 (5th Cir. 1970). For a chronology of its comeback, especially in the Second Circuit, see Herpich v. Wallace, 480 F.2d 792, 805-10 (5th Cir. 1970), and Kellogg, The Inability To Obtain Analytical Precision Where Standing to Sue is Involved, 20 BuFraro L. REv. 93 (1970).

18 See text at note 73 infra. 
ance as a problem of proof of damages. As the Second Circuit said in Green $v$. Wolf, ". . . separate trial can be had on that issue as on damages." 49 Thus, possible differences in reliance do not defeat the action. No case adopting this approach has yet completed trial on the merits and therefore reached the problem of making separate determinations of reliance for each member of the class. However, when a class numbers in the thousands it is somewhat unrealistic to expect that each class member will be called into court for the purpose of determining reliance.

Reliance presents a much more difficult factual inquiry than does the damage issue. ${ }^{50}$ The latter will typically require only some indication of a purchase or sale in the time period of liability-a matter which can be handled by a master without an adversary process. Reliance, on the other hand, involves intensive examination of the plaintiff's conduct, background and state of mind. It has been the central issue in many $10 \mathrm{~b}-5$ individual actions. ${ }^{51}$ These considerations make it likely that deferring the reliance inquiry effectively eliminates the dispositive effect of reliance.

Some courts, apparently unsure of their footing, simply allow the problem of reliance to drop from sight unresolved. In Harris $v$. Palm Springs Alpine Estates, Inc.,52 a suit alleging misrepresentations in con-

49406 F.2d 291, 301 (2d Cir.), cert. denied, 395 U.S. 977 (1968). Judge Kaufman went on to state: "The effective administration of $23(\mathrm{~b})(3)$ will often require the use of the 'sensible' device of split trials," (emphasis added) citing Frankel, Some Preliminary Observations Concerning Rule 23, 43 F.R.D. 39, 47 (1966). 406 F.2d at 301. However, Frankel's language was somewhat incorrectly inscribed, for he said, "familiar device of split trials." Moreover, Judge Frankel failed to inform us of the sources of this "familiarity," especially with large classes. We still await the appearance of separate reliance trials in Green. Plaintiffs, apparently not pleased with the prospect, are attempting to steer a new course. In Green v. Wolf, 50 F.R.D. 220, 222-23 (S.D.N.Y. 1970), they successfully amended their complaint. Originally they had claimed to rely on misleading prospectuses. Now, they claim that cash distributions made to shareholders were in excess of cash actually available, and if they had known this fact, they would not have purchased stock. They thus seek to convert a claim of misrepresentation to one of non-disclosure, thereby seeking to minimize the reliance requirement. Many cases have indicated a willingness to follow the "split trial" method of dealing with reliance. See Epstein v. Weiss, 50 F.R.D. 387, 393-94 (S.D. N.Y. 1970); Fogel v. Wolfgang, 47 F.R.D. 213 (S.D.N.Y. 1969); Cannon v. Texas Gulf Sulphur Co., 47 F.R.D. 60, 64 (S.D.N.Y. 1969); Mersay v. First Republic Corp:, 43 F.R.D. 465, 471 (S.D.N.Y. 1968).

50 See Morris v. Burchard, CCF FED. SEc. L. REP. If 92,910, at 90,389 (S.D.N.Y. 1971) (Pollack, J.). However, the district courts have not abandoned hope altogether. The "split trials" solution was recently adopted in Feder v. Harrington, CCF FED. SEC. L. REP. I 92,903 (S.D.N.Y. 1970).

51 Cases cited note 29 supra.

52329 F.2d 909, 914-15 (9th Cir. 1964). It is altogether conceivable that the Harris court envisioned "split trials" since it relied on Barber v. Tadayasu Abo, 186 F.2d 775 (9th Cir. 1951), a class action for habeas corpus on behalf of persons held in custody for deportation to Japan. However, in Barber "separate trial" consisted of affidavits submitted 
nection with investments in a real estate company, the court stated that possible differences in reliance would not defeat the class action as long as common questions predominated. But it did not say that individual members of plaintiff class need not show reliance, nor did it advise the district court on the efficient disposition of thousands of factual inquiries regarding reliance.

Another possible treatment of reliance in class actions is to change, rather than eliminate, the substantive requirement. Thus, a court could ask whether the "reasonable investor" would have relied. This standard eliminates the necessity for more than one factual inquiry, since all plaintiffs are, presumptively, reasonable investors. This formulation of the reliance element, may, however, be a mark of its demise, for the new definition is perilously close to the definition of materiality in $S E C$ v. Texas Gulf Sulphur Co. ${ }^{53}$ If the test of materiality is whether a reasonable man would attach importance to a fact, it is hard to conceive of a situation where importance would be attached by a reasonable man but where a reasonable man would not rely. Thus, in Gerstle v. Gamble Skogmo, Inc., ${ }^{54}$ an action under section 14(a) and SEC rule 14a-9, the court remarked that "if the 'reasonable man' test has been satisfied ... personal reliance can be inferred and reliance by the individual shareholder may be inferred." ${ }_{55}$ There can be little doubt that this definition departs significantly from the $L$ ist test of causation in fact.

Still other courts deal with reliance by finding that it exists a priori. Thus, in Weisman v. M.C.A., Inc., ${ }^{56}$ the court proposed that reliance exists whenever there is a purchase of stock-which is always. Even if

by the party plaintiff showing the intention of those in custody to renounce their Japanese citizenship to avoid deportation, hardly a precedent for separate evidentiary hearings in a 10b-5 damage action. Other courts have left us with similarly vague resolutions. See Mader v. Armel, 402 F.2d 158, 163 n.20 (6th Cir. 1968) (plaintiffs required to support by evidence the allegations of their complaint); Astor v. Texas Gulf Sulphur Co., 306 F. Supp. 1333, 1342 (S.D.N.Y. 1969) ("Plaintiffs have stated claims under Rule 10b-5 . . . Determination of liability, what damage, if any, plaintiffs suffered and what remedy is appropriate, must await trial."); Dolgow v. Anderson, 43 F.R.D. 472, 491 (E.D.N.Y. 1968).

53 See text at notes $42-43$ supra. It should be noted that the acceptance by the Second Circuit of the "reasonable investor" test, 401 F.2d at 849, in the SEC action was made while 49 private actions were pending in the district court, 31 of which were class actions. See SEC v. Texas Gulf Sulphur Co., 258 F. Supp. 262, 263 n.I (S.D.N.Y. 1966).

54298 F. Supp. 66 (E.D.N.Y. 1969). Although the court was not willing to say reliance was equivalent to materiality in a $10 \mathrm{~b} .5$ action, its reasoning in the proxy context reaches this result. The court states, "[T] stances reliance . . predicated upon material misrepresentations in the proxy statement." Cf. Berman v. Thomson, 45 F.R.D. 342 (N.D. Ill. 1968), and see Comment, Negligent Misrepresentations Under Rule 10b-5, 32 U. CHI. L. REv. 824, 842 n.75 (1965).

55298 F. Supp. at 98.

5645 F.R.D. 258, 269 (D. Del. 1968). A similar approach was suggested in Mader. See text at note 23 supra. 
the case involves a sale, there must necessarily have been a prior purchase. The court viewed reliance as characteristic of all holders of stock in that they rely on the good faith and fair dealing of corporate management.

A similar form of a priori reliance relates to market prices. In Herbst v. Able ${ }^{57}$ the court found a material omission of fact and misrepresentations resulting in overstated earnings. Plaintiff class was comprised of holders of convertible debentures who exercised their conversion rights during the omission-misrepresentation period. The court reasoned that since the market price of the stock went up during the omission period, and since all purchasers (holders of convertible debentures) "presumably" react to increased market prices, there was a fraud on the market common to all members of the class. Thus, through the heroic assumption that market prices are the sole explanation for purchases, the court neutralized differences in reliance. Other courts reason similarly to achieve the same result. ${ }^{58}$

A few courts have yielded to the common question dilemma by stating that reliance is not a necessary element of a cause of action under 10b-5. Thus, in Kahan $v$. Rosenstiel, ${ }^{59}$ a suit for attorney's fees, the Third Circuit had to decide whether a mooted class action in which Kahan had been counsel had stated a meritorious cause of action. The court stated that "proof of reliance is not an independent element which must be alleged to establish a cause of action," 60 because it would make recovery for the class difficult and because any material defect in a statement carries with it the implication that a "reasonable shareholder" had relied."

The tide may be turning toward express elimination of reliance with the Supreme Court's decision in Mills $v$. Electric Auto-Lite Co. ${ }^{62}$ In

57 47 F.R.D. 11, 16 (S.D.N.Y. 1969).

58 Judge Weinstein did not rule out this result in Dolgow v. Anderson, 43 F.R.D. 472, 488-90 (E.D.N.Y. 1968). A variant of this approach is indicated in Esplin v. Hirschi, 402 F.2d 94, 100-01 (10th Cir. 1968), where the court states: "Investors did not rely upon oral misrepresentations at all, or for that matter upon any affirmative misrepresentations, but upon a complete failure to disclose any material facts-which default was necessarily common to all shareholders." This formula demonstrates the semantic ease with which any case involving a misrepresentation can be converted to a non-disclosure case. See Green v. Wolf, 50 F.R.D. 220, 222-23 (S.D.N.Y. 1970), and note 49 supra. But see Crane Co. v. Westinghouse Air Brake Co., 419 F.2d 787, 797 (2d Cir. 1969), cert. denied, 400 U.S. 822 (1970).

59424 F.2d 161, 173-74 (3d Cir. 1970) (Adams, J.), rev'g 300 F. Supp. 447 (D. Del. 1969), cert. denied, 398 U.S. 950 (1970).

$60 I d$. at 173 .

61 Id. at 174. In reaching this result the Third Circuit partially relied on Mills v. Electric Auto-Lite Co., 396 U.S. 375 (1970), and sought to apply the reasoning in that case, see text at notes $62-70$ infra, to the $10 \mathrm{~b}-5$ area.

62396 U.S. 375 (1970) (Harlan, J.), rev'g 403 F.2d 429 (7th Cir. 1968), rev'g 281 F. Supp. 826 (N.D. III. 1967). 
Mills plaintiffs sued derivatively and as a class of minority shareholders to set aside a merger, alleging a failure by Auto-Lite's directors to disclose in a proxy statement recommending the merger that they were under the control and domination of the acquiring company. The suit was grounded on section 14(a) of the 1934 Act and SEG rule 14a-9.93 The district court, ${ }^{64}$ ruling on plaintiffs' motion for summary judgment, decided that there was a material omission, but that a hearing would have to be held to determine whether there was a causal connection between the omission and the injury. After the hearing, the court held that since the votes of minority shareholders were necessary to approve the merger, the requisite causal relationship had been shown. The court of appeals reversed on the causation point, explaining that the test of causation was the same as the test of reliance-whether the injured parties relied on the misrepresentation. ${ }^{65}$ However, "rightly"66 concluding that it would be impossible to determine the reliance of thousands of individuals, the Seventh Circuit adopted another test: plaintiffs would prevail unless defendants could show that the merger was fair. ${ }^{67}$ Justice Harlan's opinion for the Supreme Court rejected this fairness approach, ${ }^{68}$ holding instead that where "the proxy solicitation itself, rather than the particular defect in the solicitation materials, was an essential link in the accomplishment of the transaction,"69 reliance need not be established.

Mills clearly does not dispose of the reliance question in $10 \mathrm{~b}-5$ actions. At least three circuit courts have referred to reliance as a necessary element in a claim since Mills-in individual actions. ${ }^{70}$ But, faced with

63 17 C.F.R. § 240.14a-9 (1970).

64281 F. Supp. at $830-31$.

65 403 F.2d at 436 \& n.10.

60 This is Justice Harlan's characterization of the Seventh Circuit's conclusion. He also notes, 396 U.S. at 382 n.5, that "[p]roof of actual reliance by thousands of investors would, as the court acknowledged, not be feasible," citing R. JENnINGs \& H. MARSH, JR., supra note 27 , at 1001 .

67396 U.S. at $380 ; 403$ F.2d at $435-36$.

68 Id. at 386 . The Court dismissed List $v$. Fashion Park with a brief "cf." Id. at 384 n.6.

69 For what the "essential link" holding may mean see Note, Causation and Liability in Private Actions for Proxy Violations, 80 Yale L.J. 107 (1970). Unhappily, the Note attributes no special importance to the fact that Mills was a class action. Mills has been cited with approval in a proxy case class action brought under both 10b-5 and 14(a). Gould v. American Hawaiian Steamship Co., CCH FED. SEC. L. REP. If 92,864 (D. Del. 1970) (Wright, C.J.), but Judge Wright rested his decision only on the count under 14(a), stating that under Mills this section was more favorable to plaintiffs' case. But see discussion of Kahan in text at notes 59-61 supra.

70 City Nat'l Bank v. Vanderboom, 422 F.2d 221, 231 (8th Cir. 1970), puts an interesting twist on the requirement. It first adopts the "reasonable investor" test but then reintroduces the individual plaintiff by looking at his characteristics to see if he is reasonable. Gilbert v. Nixon, 429 F.2d 348, 355 n.15 (10th Cir. 1970), dismisses Mills with a brief "cf." Also, see Chasins v. Smith Barney \& Co., CCH FED. SEc. L. REP. I 92,712, at 99,137 (2d Cir. 1970), which gives Mills a "see also" after relying on List. 
"thousands of investors" who may or may not have relied, all three courts in Mills accommodated the class by restricting the reliance element. The same problem of determining reliance by each of the "thousands of investors" in a class suit must be resolved under 10b-5. Indeed, the reliance cases so far reviewed indicate that $10 \mathrm{~b}-5$ law is fast approaching the Mills result.

The attenuation or abolition of reliance is not, however, unambiguous. Some courts have dismissed class actions because questions of reliance were not common to the class; the reasoning in these cases is of some interest.

In Berger v. Purolator Products, Inc. ${ }^{71}$ the court approved dismissal of two class actions that had been settled by the plaintiff-representative. In determining under rule 23 whether the settlement was fair to the class and, thus, whether the actions were properly dismissed, the court noted, citing $L i s t$, that differences in reliance made plaintiffs' success unlikely. This was a better prediction in 1966 than it would be in 1971 . Also, since it is unclear what happens if the court does not approve a settlement, ${ }^{72}$ the court may have been anxious merely to state a basis for approving it.

In Kronenberg $v$. Hotel Governor Clinton, Inc. ${ }^{73}$ the defendants themselves were in the plaintiff class! They had simultaneously purchased securities and induced the purchase of others by fraud. Thus, absent a reliance element, defendants might recover from themselves. This anomaly is not unusual, though it is rarely presented so starkly. If reliance is abolished, some who did not rely will recover; if reliance is retained, either the action must be dismissed for non-common questions or great time and resources must be spent to ascertain its existence. Faced with these undisguised facts, Kronenberg avoided the anomaly by preserving the reliance requirement for the purpose of proving damages. Defendants could be excluded from recovery at that time. Other courts, apparently unimpressed with the anomaly, have restricted reliance when the alternative would have been dismissal or separate investigation.

The only recent case to dismiss a class action because of possible differences in reliance among the members of the class is Hirsch $v$. Merrill Lynch, Pierce, Fenner \& Smith. ${ }^{74}$ This action, part of the extensive

7141 F.R.D. 542 (S.D.N.Y. 1966).

72 See Newberg, Orders in the Conduct of Class Actions: A Consideration of Subdivision (d), 10 B.C. IND. \& COM. L. REv. 497, 592 n.43 (1969).

7341 F.R.D. 42 (S.D.N.Y. 1966).

74311 F. Supp. 1283, 1289 (S.D.N.Y. 1970). Jacobs v. Paul Hardeman, Inc., 42 F.R.D. 595, 599 (S.D.N.Y. 1967), reaches the same result on similar facts. 
Douglas Aircraft litigation, ${ }^{75}$ was brought on behalf of those purchasing Douglas stock between June 20 and June 24, the period during which . Douglas left an inaccurate earnings statement in force. Plaintiff, however, did not sell until six months after Douglas issued a corrective release. The court held that the late sale indicated that plaintiff's loss had not been caused in fact by the misrepresentations. ${ }^{76}$ The party-plaintiff was apparently seeking to take advantage of the misrepresentation to recoup losses attributable to a general down swing in the market. As in Kronenberg, the facts were hard; but the Hirsch court adopted a harsher alternative than the exclusion solution of Kronenberg: it dismissed the action, denying relief to the entire class. ${ }^{77}$

A final case presents a stronger challenge to the elimination of reliance and threatens the continued use of class actions under 10b-5. In Korn v. Franchard Corp..$^{78}$ a class of 1,000 investors in a real estate venture alleged a misrepresentation in a 1961 prospectus describing the terms of their investment in a real estate syndicate. Judge Mansfield had previously maintained the action on a class basis, but only conditionally, ${ }^{79}$ pending the return by members of the class of proof of claim forms. ${ }^{80}$ The forms were designed to ascertain whether the members of

75 See Herbst v. Able, 47 F.R.D. 11, 16 (S.D.N.Y. 1969).

76311 F. Supp. at 1289.

77 Id. at 1290.

78 CCH FED. SEC. L. REP. I 92,616 (S.D.N.Y. 1970) (Mansfield, J.).

79 Courts may maintain class actions on a conditional basis. See Dolgow v. Anderson, 43 F.R.D. 472, 502 (E.D.N.Y. 1967); Leader, supra note 3, at 422-23; Wright, supra note 3 , at $181-82$.

80 Judge Mansfield stated that the proof of claim form procedure "has gained favor in similar class suits." The cases used by the court to support this proposition are, however, less than controlling. Three of them involved antitrust claims made by governmental entities in which the proof of claim form was restricted to proof of damages, e.g., purchases and prices. See Minnesota v. United States Steel Corp., 44 F.R.D. 559, 577 (D. Minn. 1968) (objective facts relating to purchases); Iowa v. Union Asphalt \& Roadoils, Inc., 281 F. Supp. 391, 404 (S.D. Iowa 1968) (indicate in writing intent to submit claims); Philadelphia Elec. Co. v. Anaconda Am. Brass Co., 43 F.R.D. 452, 462, 464 (E.D. Pa. 1968) (proof of damages). The weakness of the antitrust cases as precedent lies in the difference between the forms employed there, and the one in Korn, which asked a substantive question-did you rely on the misrepresentation? Moreover, the attentiveness of governmental bodies, whose individual claims might amount to thousands of dollars and whose recordkeeping procedures allow easy recall of information, differs substantially from the lack of interest likely where a ten dollar investor is involved. The one reported securities case relied on by the court is Harris v. Jones, 41 F.R.D. 70 (D. Utah 1966), which required a pretrial processing of proof of claim forms before the action could be maintained on a class basis and submitted substantive questions in regard to reliance on misrepresentations. Id. at 73. However, the court recognized that this might be in conflict with the provisions of rule $23 . I d$. at 75 n.10. The case had not been cited favorably until Korn.

The proof of claim form procedure bears a strong resemblance to earlier attempts to have "evidentiary hearings" on the merits before the action could proceed on a class basis. Dolgow v. Anderson, 43 F.R.D. 472, 502 (E.D.N.Y 1968). For later cases disapproving of 
the class were favorably disposed to the suit and whether they had relied on the alleged misrepresentations. ${ }^{81}$ Upon return of the forms, defendants' motion for dismissal under rule $23(c)(1)$ was granted, in part, because of the results of the form..$^{82}$

The returned forms showed that the class was apathetic to the action. ${ }^{83}$ Further, a "substantial number" stated that they did not rely on the prospectus though the form "was an invitation to so state;" 84 and eighty per cent of the class would not state "even in the most general terms what if anything was misstated." 85 Finally, many investors indicated that they had relied on the advice of other people in making their investment.

The court offered an explanation for the apathy. Six months after the initiation of the suit, the defendant corporation had liquidated and distributed to its investors $\$ 4,570$ for each $\$ 5,000$ investment unit. The lawsuit was mentioned in the distribution letter and each distributee could release Franchard Corporation and its executives from any claims by signing a statement on the back of the enclosed check. Only seventy recipients of the checks refused to sign. ${ }^{86}$ The low rate of re-

this approach, including Green v. Wolf, 406 F.2d 291, 301.02 n.15 (2d Cir. 1968), see Ieader, supra note 3, at $427-28$ \& n.68. The grounds of disapproval are redundancy, impermissible modification of summary judgment and denial of plaintiff's right to jury trial. The latter problem may be of greater importance in light of the "flexible" approach to the jury trial taken by the Supreme Court in Ross v. Bernhard, 396 U.S. 531 (1970). See Comment, Jury Trial in a Stockholder's Derivative Suit, 65 Nw. U.L. REv. 697 (1970).

8150 F.R.D. at 60 . Judge Mansfield did not indicate that the answers to the proof of claim form could lead to dismissal.

82 Reversal also rested on another ground. The court noted that plaintiffs' attorney might have violated Canons 2, 11 and 28 of the Judicial Ethics, ABA Code of Professional Responsibility, by stirring up litigation through communication with the class under a pseudonym letter while the proof of claim form was outstanding. The court rejected any comparisons between the conduct of plaintiffs' attorney and that of defendants' use of a release form during the same period. CCF FED. SEc. L. REP. I 92,616, at 90,169. But see Kahan v. Rosenstiel, 424 F.2d 161, 169 (3d Cir. 1970) (rule 23(e) requires court approval of settlement). See also Manual for Complex and Multidistrict Litigation: Suggested Local Rule No. 7-Prevention of Potential Abuses of Class Actions, 49 F.R.D. 217, 229 (1970).

83 Of the 1,000 forms sent out, $36 \%$ were undelivered because the persons had changed their address and had left no forwarding address. The court noted that of the 233 responses returned, 77 had requested exclusion from the class. The only other empirical evidence attesting to apathy on the part of the class was that $80 \%$ to $90 \%$ of those returning the form were unable to state the amount received by them upon sale of their investment. The validity of these results, in terms of the adequacy of the sampling technique-or the propriety of basing any judicial decision on the basis of a mail sample - was not discussed by the court.

$84 \mathrm{CCH}$ FED. SEC. L. REP. If 92,616, at 90,167.

$85 \mathrm{Id}$.

80 Id. 
fusal was evidence, the court felt, that plaintiffs' interests were not typical of the asserted class. ${ }^{87}$

Use of proof of claim forms to determine reliance raises several problems. The forms are necessary only if reliance is preserved as an element of a 10b-5 claim, yet the very use of the form may transform reliance into a formal, but significant, obstacle to recovery. Many class members are not likely to understand the technical notion of reliance. Moreover, as discussed by Judge Mansfield, there are objections to the propriety and validity of conducting an evidentiary hearing through the mail. Mansfield felt that the class action was designed to protect small investors "unable to articulate their claims with the precision demanded of larger more sophisticated claimants." $88 \mathrm{He}$ also noted the inherent difficulties of asking investors with small claims to track down information to answer questions. ${ }^{89}$

Another alternative, rejected by Mansfield, is exclusion from the class of those indicating no reliance. If those class members do not indicate also that they are requesting exclusion from the class, this alternative may be contrary to rule 23 , which requires inclusion in the class unless exclusion is requested. ${ }^{90}$ The same problem would be encountered in excluding those who fail to file a proof of claim form. ${ }^{91}$

87 Rule 23(a)(3) provides that a class action may be maintained only if "the claims or defenses of the representative parties are typical of the claims or defenses of the class." This test is probably equivalent to that of "common questions." See 3B MOORE's FederaI. Practice \$ 23.06-2, at 23-325, -326 \& nn.5 \& 6 (2d ed. 1969).

88 50 F.R.D. at 60 .

89 Id. The court states that: "Unless and until liability to the class is established or seems reasonably certain, therefore, members should not be barred for failure to track down this information, even though such information might later be a reasonable condition to their participation in any recovery, assuming liability is established."

80 FED. R. CIv. P. 23(c)(3). See Kaplan, supra note 3, at 391-92.

91 Judge Mansfield seemingly took this point of view in the first action, stating: "However, there appears to be a fundamental inconsistency in providing, on the one hand, that.a member who fails to request exclusion shall be included in the class and, on the other hand, that a member who fails to file a proof of claim shall be excluded from any recovery." 50 F.R.D. at 60.

Neuman v. Electronic Specialty Co., CCH FED. SEc. L. REP. I 92,591 (N.D. IIl. 1969), where proof of claim forms were used as the basis of settlement, raises as many problems as Korn, where the forms were used to justify dismissal of the action. Plaintiff class in Neuman consisted of approximately 9,000 holders of 900,000 shares (or the debenture equivalent) of Electronic Specialty. When Electronic Specialty became the target of a tender offer, the corporate directors recommended that the shareholders reject the offer; jet on the day the offer was to expire, the officers tendered their shares. Plaintiffs charged the corporation and its officers with misrepresentations in the communications to the shareholders in violation of rule $10 \mathrm{~b}-5$ and $\S 14(\mathrm{e})$ of the Securities Exchange Act and clained as damages the difference between the tender offer $(\$ 39)$ and the price at which plaintiffs could have or did sell their shares (\$33 $3 / 8$ the day after the offer expired).

Judge Will upheld the action on a class basis but required each member of the class to prove reliance. He directed that a letter be sent to the members of the class; the letter 


\section{Furthermore, in any solicitation of a large class, some members will never receive forms, some members will not return forms and some}

\section{included three questions pertaining to reliance:}

5. Did you rely on the letter attached hereto [this was the letter in which the defendants urged the shareholders not to tender] in deciding whether or not to tender your stock or debentures?

6. If you answered yes to Question 5, what, if any, other factors caused you not to tender your Electronic Specialty Co. stock and debentures to International Controls Corp.?

7. If you answered no to Question 5, what factors caused you not to tender your Electronic Specialty Co. stock and debentures to International Controls Corp.?

After 30 days a second letter, indicating that non-respondents would be barred from recovery, was sent to the entire class.

$35 \%$ of the members of the class (holders of 453,000 shares) indicated reliance. Another $15 \%$ of the class members responded to the questionnaire, with some indicating no reliance and others (holders of 129,000 shares) opting out of the class. $50 \%$ of the class failed to respond.

The parties entered into settlement negotiations and calculated damages using as a guideline the number of reliers as revealed by the form. On January 28, 1971, Judge Will approved the resulting settlement of $\$ 1.2$ million (of which $\$ 240,000$ was allocated to attorney fees). His order restricted participation in the settlement to members of the class who had indicated reliance. When notice of the settlement was sent out, some class members, who apparently had never heard of the suit, demanded inclusion as reliers; others indicated that they had more shares than were shown by the settlement schedule. Plaintiffs' counsel is now amending the schedule on the basis of these adjustments, but there has been no increase in the gross damage award. This outline of Neuman comes from an interview with Lowell Sachnoff, Gerald Fishman, and Ron Grais, of Sachnoff, Schrager, Jones \& Weaver, attorneys for the plaintiffs, Chicago, Illinois, Feb. 9, 1971.

There seem to be four difficulties with the Neuman use of proof of claim forms. First, there is the Korn problem of conducting a trial investigation through the mail. This concern is particularly acute in Neuman since the form determines who will participate in a settlement which binds all members of the class who have not opted out. Class members probably are not familiar with the meaning in legal parlance of "reliance." Since counsel may not communicate with the class, or otherwise define the meaning of the term, many class members who do respond may do so blindly. The result may be as many different standards of reliance as there are members of the class.

Second, since many respondents to the form used in Neuman gave highly ambiguous or confused answers, there were difficult problems of classifying responses. This task is more difficult than in Korn, where the common questions issue required only a rough delineation of reliers and non-reliers. In Neuman precise delineation was necessary, but there was no clear categorization of those situations where reliance is present and those where it is not. For example, does reliance on the advice of a friend who himself relied on the misrepresentation constitute cognizable reliance? Even if there were categories, problems of determining what the respondent meant to say would remain.

Third, the procedure creates tensions with the opt-out requirement of rule 23(c)(2). That section provides that a judgment "will include" each class member who has not requested exclusion. While non-respondents (or non-reliers) to the form have not requested exclusion and are therefore bound by the settlement, they are excluded from participation in the settlement. This anomaly is aggravated by the consideration that many members of the class, particularly those whose stock was held in street name, never received the form. This non-receipt may admittedly be due to understandable practical problems, but it is difficult to comprehend why the street-name or mobile class member should be disadvan. taged with regard to settlement. This defect is not cured by recurring to the "best rea. 
members will profess non-reliance. The differences will always, under Korn, raise a non-common questions issue leading, perhaps, to dismissal.

If reliance remains a meaningful element of a 10b-5 claim, Korn $v$. Franchard indicates that class actions will seldom withstand attack. Nevertheless, the implication is, as in cases where reliance is eroding, that expanded use of class actions requires the elimination of substantive elements which demand particularized examination of class members.

One court has recently recognized the inability to maintain reliance within the context of the class action. The frank opinion of Judge Pollack in Morris $v$. Burchard ${ }^{22}$ hopefully portends more open discussion in future cases of the substantive law choice now facing the courts in class actions. Plaintiffs had bought allegedly unregistered stock of the Lynbar Corporation from a group of brokers. In a class action, with a count under $10 \mathrm{~b}-5,93$ plaintiffs claimed that the Lynbar stock was sold by means of untrue oral statements of material fact. The case was before Judge Pollack on a motion to maintain the suit as a class action.

The court began its analysis by observing that the series of oral misrepresentations appeared disconnected and varied with regard to each member of plaintiff class. This raised the issue of "material variations in what the purchasers relied on and whether they did rely on any of the asserted misrepresentations." 94

Judge Pollack then rejected the "split trial" solution of the Second Circuit in Green v. Wolf as a "harrowing experience" that could "transform a litigation into a gigantic burden on the Court's resources beyond its capacity to manage or effectively control." 95 Judge Pollack then observed,

sonable notice" standard of Mullane v. Central Hanover Bank \& Trust Co., 339 U.S. 306 (1950), for that standard is relevant only to binding absent class members, not to excluding a bound class member from the settlement.

Finally, there is a representation problem when, as is understandable, the results of the form come to be used as a guideline in settlement negotiations. The damages of nonrespondents are not accounted for in the settlement, and the cause of the non-reliers is left with no champion. Since a large settlement itself provides generous attorney fees, it may not be in the interest of the attorneys who have been handling the case to argue either that the settlement amount should be much larger than is indicated by the number of reliers or that (for the sake of non-reliers) there is no reliance requirement under $10 \mathrm{~b}-5$. The practical opportunity for absent class members to intervene is limited, and the court is unlikely to provide protection for these groups if it has been instrumental in establishing the challenged use of forms.

92 CCH FED. SEC. L. REP. ๆ 92,910 (S.D.N.Y. 1971).

93 Another count, which was stated under $\S 5$ of the 1933 Act, pertaining to sale of unregistered securities, was upheld within the class action context. See note 120 infra.

94 CCH FED. SEC. L. REP. I 92,910, at 90,389.

95 Id. Judge Pollack has been active in attempting to improve the efficiency of the courts in handling their workloads. See Pollack, Pretrial Conferences, Judicial ConferenceEighth Gircuit, 50 F.R.D. 427, 467 (1970). 
The practical possibility then, is that the use of the procedural remedy of a class suit might provide an administrative need, if not incentive to erode and impair observance of the substantive law requirements for compensable claims under the Securities Laws. ${ }^{96}$

Characterizing potential $10 \mathrm{~b}-5$ claimants as speculators disappointed by market conditions, the court dismissed the count under $10 \mathrm{~b}-5$.

2. In Pari Delicto. Due to the relatively recent development of this defense, it appears in only a few class actions. Within the framework of common questions, the defense arises through a challenge by defendant that some members of the plaintiff class are in pari delicto and others are not. Like reliance, this defense can be used to undercut commonality; it requires detailed factual investigation of the conduct and state of mind of each class member. Two restrictions on defendant's ability to assert the defense in class actions have already been developed: postponement of the issue to the damage stage and redefinition of the defense.

In Mersay v. First Republic Corp.,$^{97}$ an action concerning alleged misrepresentations in registration statements, prospectuses and other communications issued by First Republic, defendant argued that Mersay's claim was not typical of the class. ${ }^{98}$ Defendant claimed that Mersay's close association with defendants prior to and after the formation of First Republic made him an insider, thus disqualifying him as a representative of the class of innocent shareholders. ${ }^{99}$ The court reasoned that this defense related only to Mersay's ability to recover damages, stating that "Mersay's status as an insider may defeat his individual claim, just as other claimants' right to recover may be defeated by other defenses."100

Postponement of an affirmative defense to the damage stage does not present the same difficulties as does postponement of an element which plaintiff must prove. Conceivably, defendant could easily identify individual members of plaintiff class who are in pari delicto and then offer proof to preclude their recovery. This is a likely strategy if a particular class member has large damages-if he bought or sold a big block of shares. Such a strategy requires only a limited number of factual inquiries. On the other hand, if defendant asserts the defense on a wide

96 CCH FED. SEC. L. REP. I 92,910, at 90,389 (S.D.N.Y. 1971). Judge Pollack also noted the problem of multiple jury trials, citing Lah v. Shell Oil Co., 50 F.R.D. 198, 200 (S.D. Ohio 1970).

9743 F.R.D. 465 (S.D.N.Y. 1968).

98 Id. at 467 . See note 87 supra.

9943 F.R.D. at 468.

$100 \mathrm{Id}$. 
scale, individual inquiries could proliferate, raising problems similar to those created by postponement of the reliance question.

In pari delicto has also undergone redefinition in class actions. In Carpenter $v$. Hall ${ }^{101}$ a trustee in bankruptcy brought a class and derivative action on behalf of those who had sustained a loss resulting from purchases of or loans against the common stock of the debtor corporation. ${ }^{102}$ The losses occurred allegedly as a result of misrepresentations by a class of 93 defendants. Defendant representative claimed that the plaintiff corporation was in pari delicto and thus unqualified to bring suit. ${ }^{103}$ The court reasoned, however, that plaintiffs could be barred only if they were at more than equal fault in the transaction. ${ }^{104}$ This standard substantially limits the defense as defined in Kuehnert, yet the court engages in none of the policy discussion contained in the Kuehnert decision. Only rarely could a tippee be at greater fault than a tipper, ${ }^{105}$ so the Carpenter standard may impose no obstacle at all. In any case, the effect of Carpenter is to change the substantive requirement and eliminate its consideration at trial on the merits.

3. Materiality. Unlike reliance and in pari delicto, the requirement that a misrepresentation or omission be material generally does not provide a basis for differentiating members of a plaintiff class. The cause of action arises out of some incident of alleged misconduct by defendant. If that incident is material for one member of the class, it is material for all members of the class. In these situations, the materiality notion remains strong. ${ }^{106}$

However, in another setting-where several minor and usually differ-

101311 F. Supp. 1099 (S.D. Tex. 1970) (mem.).

$102 \mathrm{Id}$. at 1103 . The inclusion of loss on loans is a novel element of damages under $10 \mathrm{~b}-5$.

103311 F. Supp. at 1106.

104 Id. at 1106. The court cited as support for this proposition Perma Life Mufflers, Inc. v. International Parts Corp., 392 U.S. 134, 146 (1970) (an antitrust class action by muffer dealers against their parent and other subsidiaries). Justice White, concurring, stated, "Generally speaking, however, I would deny recovery where plaintiff and defendant bear substantially equal responsibility for injury resulting to one of them but permit recovery in favor of the one less responsible where one is more responsible than the other."

105 Of course there are exceptions. One could extort inside information and be more at fault. In the normal case, however, fault will be greater for the insider, in possession of the information, who does not disclose to the public. As Justice Marshall, also concurring, stated, the test of the Court (Justice Black) was equivalent to a holding "that the doctrine of in pari delicto has no place in a treble damage antitrust action." See also Comment, supra note 31 , at $195-97$ (plaintiff's conduct should not bar recovery in a class action).

106 This statement holds true only within given time limits where it is agreed that the misstatement and omission could be said to affect the market or more generally the decision of the reasonable investor. Cf. Cannon v. Texas Gulf Sulphur Co., 47 F.R.D. 60 (S.D.N.Y. 1969). 
ent misrepresentations or omissions are alleged to constitute a "deceptive device"107 or an "artifice to defraud"108_the class action device facilitates a finding of materiality and thus broadens the incidence of liability under 10b-5. Green v. Wolf Corp., ${ }^{109}$ a leading case, is illustrative. Plaintiff class alleged misrepresentations in three prospectuses issued over more than a year. Each document overstated the amount of cash available for distribution to shareholders. Defendants argued that the proposed class-all those who bought stock during the yearcould not be maintained because the content and the materiality of the various statements differed. The theory was that the first of the misrepresentations may not have been material and, therefore, a member of plaintiff class who bought before the second, perhaps material, misrepresentation could not recover. The court held, however, that all the statements were alike in material respects and that even if there were differences, the series of misstatements constituted a common course of conduct in a scheme to defraud.

Similarly, in Fischer $v$. Kletz, ${ }^{110}$ where plaintiffs alleged that seven financial statements over a period of two years grossly overstated earnings, the court likened a series of misrepresentations to standing dominoes: "[O]ne misrepresentation in a financial statement can cause subsequent statements to fall into inaccuracy and distortion when considered by themselves or compared with previous statements."111 In Fischer, plaintiff representatives, who bought at the end of the line of statements, included in the class earlier buyers to explain fully the later misrepresentations.

Under the "scheme" approach, a potential plaintiff who bought after a single misrepresentation that was not itself material can nevertheless recover by instituting a class action on behalf of those in his situation, plus others who purchased after subsequent or prior misrepresentations by defendants. The plaintiff relies on these other misrepresentations to establish a scheme to defraud a class of investors. Moreover, materiality is provided by later misrepresentations or the cumulative effect of several non-material misrepresentations. ${ }^{112}$ The common questions ob-

107 Section 10(b), 15 U.S.C. $\S 78$ j(b) (1964), provides: "[It shall be unlawful] [t]o use or employ ... any manipulative or deceptive device or contrivance in contravention of such rules and regulations as the Commission may prescribe as necessary or appropriate in the public interest or for the protection of investors."

108 Rule 10b-5, 17 C.F.R. $\S 240.10 \mathrm{~b}-5(\mathrm{a})$, provides: "[It shall be unlawful] [t]o employ any device, scheme or artifice to defraud ...."

109406 F.2d 291 (2d Cir. 1968).

11041 F.R.D. 377 (S.D.N.Y. 1966).

111 Id. at 381, citing with approval Green v. Wolf, 406 F.2d 291, 300 (2d Cir. 1968). Cf.

Bateson v. Magna Oil Corp., 414 F.2d 128 (5th Cir. 1969), cert. denied, 397 U.S. 911 (1970). 112 There may also be a psychological advantage in directing the court's attention to 
jection that the statements differ fails because all statements are pursuant to the scheme. Thus, the class action device operates in conjunction with the scheme rubric to impose liability in situations where an individual action could not be successful.

One obstacle to this theory of liability is the possible requirement that the alleged misrepresentations be alike or standardized. In Moscarelli $v$. Stamm $m^{113}$ the plaintiffs alleged churning and margin violations by a defendant brokerage house. The court refused to entertain the suit on a class basis, arguing that here, unlike Green, the alleged violation related to a series of oral rather than written misstatements. Fur. ther, the court stated that it would not permit a scheme theory to circumvent the requirement that the various statements be similar.

Although oral mispresentations over time provide difficulties for plaintiffs, ${ }^{114}$ the case of the pure oral misrepresentation is not typical. Moscarelli, for example, involved personal relationships between a broker and a customer. Broker relationships were also involved in Morris v. Burchard. Due to the personal level of dealing, there is no necessity to put information in written form. This will rarely be the case where oral misrepresentations are made by public companies, for they will usually be combined with some form of written material.

Nevertheless, "standardization" remains a possible obstacle to class suits. To avoid it, class action plaintiffs in 10b-5 actions sometimes adopt a statutory liability per se approach reminiscent of Hall $v$. Coburn. ${ }^{115}$ This occurs when plaintiffs link a claim under $10 \mathrm{~b}-5$ with a claim under section 11 of the 1933 Securities Act, which establishes per se liability for a misrepresentation in a prospectus. ${ }^{116}$

the plight of the class and away from particularized factors in regard to any one plaintiff. "Class actions tend to communicate the idea of a 'public wrong' rather than a mere isolated or individual complaint." Note, supra note 3, at 648.

113288 F. Supp. 453 (E.D.N.Y. 1968).

114 The court makes the distinction between oral and written statements, as follows: "Although having some common similarities, these face to face oral misrepresentations are individualized and susceptible of material variations, particularly in view of the dis. parities in the financial condition of each member. Such differences are not the type of variations which are inherent in the garden variety of securities class action." Id. at 462-63. Since the inception of rule 23, cases involving oral misrepresentations have gone both ways. 6 L. Loss, Securtites Regulation 3947 (3d ed. 1969 Supp.). It would seem that oral misrepresentations should present no more uncommonality than written statements. In both cases the essential question is the materiality of each or all communications and whether plaintiff class relied. The distinction between thein rests on the unstated assumption that there is more difference between two or more oral statements than between two or more written ones, but this seems more a matter of proof than a prima facie case for uncommonality. See Contract Buyers League v. F \& F Inv., 48 F.R.D. 7 (N.D. Ill. 1969).

115 See text at notes 6-16 supra.

116 Securities Act of $1933 \S 11$ (d), 15 U.S.C. $\$ 77$ (1964). 
Thus, in Weiss $v$. Tenney ${ }^{117}$ plaintiff sued under section 11 and 10b-5 on behalf of those who had purchased Tenney stock between 1960-63, alleging misrepresentations in a prospectus and subsequent written statements. Plaintiff wanted the best of both worlds-the strict liability of section 11 and the more liberal damage provisions of $10 \mathrm{~b}-5.118$ The court found, in response to a non-common questions defense, that the section 11 and $10 \mathrm{~b}-5$ claims should be separate and that the section 11 class should include only those plaintiffs who purchased before "the date at which the market price of Tenney stock no longer reflected the effect of the allegedly false registration statement."110 The court granted leave to amend to define the class more adequately, tossing the ball back to the plaintiff. ${ }^{120}$ Although this approach raises difficulties in fixing a date at which prospectus misstatements will no longer have an effect on stock transactions, it allows plaintiff some latitude for expansion through strict liability and eliminates the need to show materiality.

One by-product of a broad use of the scheme theory in class actions may be the expansion of the number of defendants. This may be necessary when the misrepresentations have been made by different parties over a long period of time. Plaintiff must, in that case, show some connection between the defendants if a common course of conduct or scheme theory is to succeed. An allegation of conspiracy may provide the necessary connection. ${ }^{121}$ The most striking use of a scheme-plus-

11747 F.R.D. 283 (S.D.N.Y. 1969). There was also a count under $\$ 17$ (a), 15 U.S.C. $\S 77 q(a)$ (1964).

118 The maximum damages available under $\S 11$ is the initial offering price. 15 U.S.C. $\S 77 \mathrm{k}(\mathrm{g})(1964)$.

11947 F.R.D. at 289.

120 For a display of confusion by the trial court about what the cutoff point should be, see id. at $288 \mathrm{n}$.l. For a variant of plaintiffs' approach in Weiss, see Rosen v. Bergman, 40 F.R.D. 19, 21 (S.D.N.Y. 1966), in which the court granted intervention to a plaintiff suing on behalf of a class, under $\S 11$, in what was formerly a $10 \mathrm{~b}-5$ action. The court notes that a valid $\S 11$ complaint also states a valid $10 \mathrm{~b}-5$ action, if fraud is involved-usually the case. See Fischman v. Raytheon Mfg. Co., 188 F.2d 783, 787 (2d Cir. 1951). In Morris v. Burchard, CCH Fed. SEc. L. REP. \ 92,910 (S.D.N.Y. 1971), Judge Pollack upheld a complaint on a count under $\S 5$ of the Securities Act of 1933, 15 U.S.C. $\S 77$ e (1964), which establishes liability for selling an unregistered security, while dismissing the other count under 10b-5. See text at notes 92-96 supra. The court rejected defendants' argument that $\S 12(1)$ of the 1933 Act, 15 U.S.C. $\$ 771$ (1964), limited a plaintiff to recovery against his immediate seller. The court held that the $\$ 5$ requirement of privity, "that any person who offers or sells a security in violation of section $5 \ldots$ shall be liable to the person purchasing such security from him . ..." was satisfied by the allegation of conspiracy against the twenty-six defendants. The rationale of the holding lies in the court's observation that if the scheme and the fact of non-registration were established, plaintiff class would recover without any necessity for split trials on individual issues, a result not possible under the $10 \mathrm{~b}-5$ count without a change in substantive law. One might note, however, that Judge Pollack's reading of $\S 5$ is not without its own implications for change.

121 The use of this theory is traceable to antitrust precedents. See Weeks v. Bareco Oil Corp., 125 F.2d 84, 88 (7th Cir. 1941), which held that an illegal conspiracy gives rise to 
conspiracy approach to ease materiality requirements occurred in Harris v. Palm Springs Alpine Estates, Inc. ${ }^{122}$ A class of investors in a "secured 10\% Earnings Program" of the Los Angeles Trust Deed and Mortgage Exchange sued the company, its officers and 40 groups of real estate subdividers. The court seems to have relied on a prior action by the Securities and Exchange Commission, SEC v. Los Angeles Trust Deed of Mortgage Exchange, ${ }^{123}$ in holding that there was a proper allegation of both a conspiracy linking defendants and a scheme linking a number of misrepresentations for the purpose of withstanding a motion to dismiss. Given this holding, differences of materiality of misrepresentations surrounding the sale of securities to the more than 8,000 investors were of no consequence; defendant's common question defense to the class action was dismissed.

Using the scheme strategy in class actions under $10 \mathrm{~b}-5$ helps avoid problems of matching plaintiffs, time periods, misrepresentations and defendants. If plaintiff establishes a scheme, all members of the plaintiff class will have a claim against all defendants, and the materiality of

one statutory cause of action because "many persons may have the identical cause of action, arising from the same wrong, but varying in scope of damage to each depending upon the effect of the illegal act upon the individual." See also Pettit v. American Stock Exch., 217 F. Supp. 21, 29 (S.D.N.Y. 1963) (alleged conspiracy between members of the stock exchange and directors of a corporation as part of a scheme to defraud). Conspiracy theory has been used in only a few 10b-5 class actions because the usual defendants are a small group of corporate directors or brokerage firm executives. However, its use does pose the problem of requisite intent, since within the $10 \mathrm{~b}-5$ context, scienter-intent to defraud-no longer seems required. See SEC v. Texas Gulf Sulphur Co., 401 F.2d 833 (2d Cir. 1968); Stevens v. Vowell, 343 F.2d 374 (10th Cir. 1965); Ellis v. Garter, 291 F.2d 270 (9th Cir. 1961). For an analysis of the Texas Gulf Sulphur relaxation but opposition to the change, see Note, Scienter and Rule 10b-5, 69 CoLuM. L. REv. 1057 (1969). For approval, see Note, Proof of Scienter Necessary in a Private Suit Under SEC Anti-Fraud Rule 10b-5, 63 MICH. L. REv. 1070, 1079-81 (1965). The issue now is whether 10b-5 reaches negligent misrepresentations or omissions. See Epstein, The Scienter Requirement in Actions Under 10b-5, 48 N.C.L. REv. 482, 503 (1970). Although there is little authority on point, it is arguable that conscious parallelism might suffice as a substitute for intent. See Brennan v. Midwestern United Life Ins. Co., 259 F. Supp. 673 (S.D.N.Y. 1966), in which the court sustained a $10 \mathrm{~b}-5$ complaint against Midwestern, as an aider and abettor to non-disclosure of inside information by a brokerage firm. The court held that silence and inaction constituted aiding and abetting. If this is the case, allegation of conspiracy should offer future avenues for expansion. To the extent that expansion of defendant class occurs, courts may be faced with the same "thousands of defendants" problem that it faces with plaintiff classes. While this comment focuses on pressures to change substantive law requirements applying to plaintiffs, a similar analysis would apply to defendant classes. The pressures for change are attenuated somewhat by the higher motivation for defendants to participate, prompted by their potential liability. Moreover, they would. probably answer "proof of liability forms." However, if one believes that it is not proper to adjudicate liability through the mail, the proliferation of factual inquiries will still occur.

122329 F.2d 909 (9th Cir. 1964).

128186 F. Supp. 830 (S.D. Cal. 1960). 
particular misstatements need not be shown. ${ }^{124}$ But the expansion of 10b-5 liability through class actions based on a scheme to defraud is not without limitation. A scheme approach necessarily implies a larger class of plaintiffs, and there may be significant practical and procedural problems, relating to representation, conflicts among the members of the class and notice, which limit the effectiveness of this approach.

As the class expands, it inevitably will begin to include persons who do not agree they have suffered a wrong. In Eisen v. Carlisle \& Jacquelin ${ }^{125}$ plaintiff brought an action under the Sherman $\mathrm{Act}^{126}$ on behalf of all odd-lot investors alleging price fixing on the "differential" (the added commission for handling odd-lots), against the two firms in this field. As the district court noted, some members of the class (for instance, broker-dealers) might not benefit if the complaint were upheld. Due to an inability to resolve the representation issue and despite the Second Circuit's holding that this was a proper class action, the case was stalled for two years in the district court. In a recent opinion explaining the delay, ${ }^{127}$ the court voiced its concern about devising intervention procedures to accommodate the diverse interests in plaintiff class. ${ }^{128}$ No adequate solution to the representation problem seems to have been worked out in 10b-5 or elsewhere, especially in cases where the relief cannot be shaped to satisfy dissenting parties. ${ }^{129}$ The requirement of rule 23 that "the representative parties ... fairly and adequately protect the interests of the class," 130 remains an obstacle to expanded classes.

As the class expands, the probability increases also that members of the class will disagree over the theory of the case or the remedy to

124 This assumes there is no logical sub-class solution to the problem. Compare Dolgow v. Anderson, 43 F.R.D. 472, 492 (E.D.N.Y. 1968) (misrepresentations must be standardized but can be handled on a sub-class basis under FED. R. Crv. P. 23(c)(4)), not indicating whether individuals in a sub-class may use the "general scheme" to establish materiality, with Richland v. Cheatham, 272 F. Supp. 148 (S.D.N.Y. 1967) (plaintiff not allowed to maintain sub-classes timed to various omissions because of imperfect match).

12541 F.R.D. 147 (S.D.N.Y. 1966), rev’d, 391 F.2d 555, 563 (2d. Cir. 1968).

12615 U.S.C. $\$ \S 1,2$ (1964).

127 Eisen v. Carlisle \& Jacquelin, CCH FED. SEC. L. REP. I 92,830 (S.D.N.Y. 1970).

128 The court also notes problems with proving reliance. In this case it faced over 100,000 individual determinations.

129 See also Shulman v. Ritzenberg, 47 F.R.D. 202 (D.D.C. 1969) (conflict between members of class as to whether director of a joint venture should be sued on the nondisclosure of the high rate of interest paid on a loan to finance the operations of the company). The problem in civil rights cases can be acute. One court has faced the problem of deciding who speaks for the black community, CORE or the NAACP. See Norwalk CORE v. Norwalk Bd. of Educ., 298 F. Supp. 208, 209 (D. Conn. 1969) (involving a conflict as to whether the desegregation plan should provide for integration of all school districts or just white districts).

130 FED. R. CIv. P. 23(a)(4). 
request. Certain theories or remedies may benefit some plaintiffs at the expense of others. In Cannon v. Texas Gulf Sulphur Co. ${ }^{131}$ individual plaintiffs differed in the proximity of their sale of stock to the infamous April 12 press release. This led to disagreement among plaintiffs and their attorneys over the advisability of suing as a class of sellers. Those who sold near the release might be disadvantaged, from the point of view of alleging reliance, by being lumped together with those who sold later. The court allowed attorneys who wanted to proceed on a class basis to do so, while particular investors could maintain individual actions by opting out of the class. While this solution allowed objecting individuals to pursue their own litigation course, this alternative probably was realistic only for individuals with sufficiently large claims.

The same problem can occur in regard to materiality. Those believing they have a strong case for materiality at a given point in time may think their claim prejudiced, in terms of exposure to a non-common questions defense based on materiality, by expansion of the class to include other dates and misrepresentations. Another example is presented by the situation in Weiss $v$. Tenney. Those who bought one day after the prospectus, and thus had a good section 11 claim, might be prejudiced by the $10 \mathrm{~b}-5$ class joinder theory employed in the case.

Finally, as the class expands, the notice requirements, which provide that class members be informed with the best notice practicable of the suit and the right to opt out or be bound, ${ }^{132}$ can become a severe financial burden for plaintiffs. ${ }^{133}$ As the court noted in Eisen, if "financial considerations prevent the plaintiff from furnishing individual notice ... there may prove to be no alternative other than the dismissal of the class suit."134 If notice costs are prohibitive, plaintiffs may be forced to redefine the class and thus bring the action within their resources. Redefinition may, however, endanger a scheme-conspiracy theory. For example, if the Fischer class had to be redefined to include only those purchasing after a single misrepresentation, the other

13147 F.R.D. 60, 62 n.3 (S.D.N.Y. 1969).

132 See generally Comment, Adequate Representation, Notice and the New Class Action Rule: Effectuating Remedies Provided by the Securities Laws, 116 U. PA. L. REv. 889, 908 (1968).

133 The other principal alternative, having defendants bear part of the notice cost, would greatly increase the outer limits of expansion. The leading case for this alternative is Dolgow v. Anderson, 43 F.R.D. 472, 499 (E.D.N.Y. 1968). But this lead has not been widely followed. 3B MOORE's FEDERAL Practice I 23.55 (2d ed. 1969). But see Berland v. Mack, 48 F.R.D. 121, 132 (S.D.N.Y. 1969) (Mansfield, J.), for criteria of allocation of costs between plaintiffs and defendants; accord, Korn v. Franchard Corp., 50 F.R.D. 57, 60 (S.D.N.Y. 1970) (Mansfield, J.).

134391 F.2d at 570. 
dominoes would be unavailable and the action might falter on the materiality requirement.

4. Purchase and Sale. This element of substantive liability seems to survive intact in $10 \mathrm{~b}-5$ class actions. In many cases, the class may be defined simply as those who bought or sold within a certain period. Once a material violation of rule $10 \mathrm{~b}-5$ is established, individuals can easily present objective proof of purchase or sale. ${ }^{135}$ Purchase and sale is not likely to frustrate commonality under rule 23 because it does not require a detailed factual inquiry into the conduct or state of mind of the members of plaintiff class.

There are situations, however, where the court must determine whether plaintiffs' relationship to a particular transaction constitutes a purchase or sale. This was the problem in Birnbaum. In such cases the courts have resolved the issue without differentiating between members of the class. Thus, in Herpich $v$. Wallace, ${ }^{13 B}$ the Fifth Circuit treated purchase and sale as an element of the standing of the class to bring suit. The case involved an alleged conspiracy in which Wilder, the control owner of National American Corporation, sold his control for a premium to the owners of a group of companies, referred to as the Arizona Group. Payment, which was effected through a two-step process, consisted of debentures of one of the Arizona Group's subsidiaries. The Group then planned to merge National American with the subsidiary, thus forcing National American (and its shareholders) to assume the debt which reflected the premium. Plaintiff brought suit both on behalf of the class of minority shareholders of National American and derivatively against the Arizona Group to enjoin the merger and for damages already incurred from the alleged scheme to defraud. Since neither the members of plaintiff class nor the corporate entity had yet sold any stock in connection with the Arizona Group scheme, the court confronted the question of whether the purchase and sale requirement had been met. .

The court treated the issue as one of standing, and imposed two requirements grounded in article $\mathrm{III}^{137}$ of the Constitution: (1) plaintiff must show a personal stake in the controversy, and (2) the interest he

135 Even if the representative sues on behalf of a class, some of whom bought or sold and some of whom did not, the court can easily, without extended factual inquiry, limit the class to a group defined by objective facts such as purchase between specific dates.

136430 F.2d 792 (5th Cir. 1970).

137 Id. at 805 . U.S. ConST. art. III restricts federal judicial power to "cases" and "controversies." At this point the court cited Data Processing Serv. Organizations v. Camp, 397 U.S. 150 (1970); Barlow v. Collins, 397 U.S. 159 (1970); Flast v. Cohen, 392 U.S. 83 (1968); Baker v. Carr, 369 U.S. 150 (1962). A constitutional reading of $10 \mathrm{~b}-5$ standing may have the effect of broadening its scope. 
asserts must be within the zone of interests to be protected by section $10(\mathrm{~b})$ and rule $10 \mathrm{~b}-5$. After noting that the objective of section $10(\mathrm{~b})$ is to afford investors "a reasonable opportunity to make intelligent decisions regarding their purchases and sales," 138 the court found that the necessary purchase would occur when the merger was consummated. The uncompleted merger was viewed as part of a scheme to defraud "in connection with" a purchase and sale. However, the court held that the class action count in the complaint would not lie because it was the corporation and not the shareholders which would engage in the statutory sale. On the basis of this distinction, the court determined that National American, but not the members of the plaintiff class, was within the zone of interests protected by section $10(\mathrm{~b})$ and rule $10 \mathrm{~b}-5$ and therefore entitled to maintain an action. ${ }^{139}$

The significance of the preservation of the purchase and sale requirement lies in its use for determining which types of transactions at what stage of completion, such as mergers, tender offers or sale of control at a premium, shall be included within the coverage of $10 \mathrm{~b}-5$. This choice between types of transactions can be made without regard to the conduct or state of mind of individual plaintiffs. Thus, although Herpich may represent a restriction on class standing where there is a merger pursuant to sale of control at a premium, the restriction does not arise out of the difficulties connected with the management of class actions, nor does it preclude finding other transactions within the scope of the flexible Birnbaum doctrine. ${ }^{140}$

\section{Expanded Use of the Class Action Device: EXPLANATIONS AND IMPLICATIONS}

Several points emerge from this survey of $10 \mathrm{~b}-5$ liability in class actions. Some substantive inquiries, such as reliance and in pari delicto, which relate to the conduct or state of mind of plaintiff class members, have been severely restricted. ${ }^{141}$ The new emphasis is on substantive inquiries which are important in strict liability situations: (I) which type of situations are within the coverage of $10 \mathrm{~b}-5$, governed by the purchase and sale requirement, and (2) is the alleged misrepresentation material? Though this development seems not to have affected greatly

138 Id. at 806.

$138 \mathrm{Id}$. at 807 .

140 For examples of the flexible use of the purchase and sale doctrine in class actions, see Kahan v. Rosenstiel, 424 F.2d 161 (3d Cir. 1970); Mader v. Armel, 402 F.2d 158, 160 (6th Cir. 1968); Neuman v. Electronic Specialty, Inc., CCH FED. SEC. L. REP. I 92,591 (N.D. Ill. 1969).

141 As observed in note 121 supra, the same potential exists for substantive requirements pertaining to defendants. 
liability in individual actions, the impact of the change that has been occurring in the context of class actions should not be underestimated.

If, as has been maintained throughout, there is considerable friction between expanded use of class actions and retention of certain substantive requirements, ${ }^{142}$ why have the courts favored expansion of class actions? What explains the "liberal" attitude exemplified by the Tenth Circuit's holding in Esplin v. Hirschi" $i^{143}$ that any "error should be in favor of maintaining class actions"?

The first reason seems to be that class actions are designed to conserve judicial resources by avoiding a multiplicity of suits on the same issue. The need to limit the judicial workload is well recognized ${ }^{144}$ and has become a prime goal of federal judicial reform. ${ }^{145}$

Second, class actions offer compensation without participation to many investors with small claims. In many cases, courts recognize that individual actions to impose $10 \mathrm{~b}-5$ liability, though meritorious and still maintainable, would not often be pressed after dismissal of a class suit. ${ }^{146}$ Absent class members-even with notice-often do not know their rights or do not have enough at stake to justify pursuing the claim. Thus, a court, though it may recognize that certain plaintiffs have not relied, are in pari delicto, or have acted on the basis of a nonmaterial misrepresentation, may be unwilling to preclude recovery for any and all because it feels a few are unworthy.

The third major force for the expansion of class actions is deterrence of securities fraud. Even without changes in the substantive law, class actions have long been considered a potentially powerful tool for achieving the objectives of $10 \mathrm{~b}-5 .{ }^{147}$ Loosening substantive requirements serves to increase even more the potential for deterrence of $10 \mathrm{~b}-5$ violations. The most striking recent example of the damage potential of class actions is the Texas Gulf Sulphur litigation. As Ruder points out,148 the damages in that case could amount to $\$ 390$ million if all members of the selling class were to recover the difference between the price at which they sold and the top price of the stock. This is $\$ 150$ million more

142 Contra, Jennings, Insider Trading in Corporate Securities: A Survey of Hazards and Disclosure Obligations Under Rule 106-5, 62 Nw. U.L. Rxv. 809, 814-15 (1968) ("decisions construing Rule 10b-5 are creating no new substantive law of torts").

143402 F.2d 94, 101 (10th Cir. 1968). Accord, Green v. Wolf, 406 F.2d 291, 298 (2d Cir. 1968).

144 See generally Friendly, Is Innocence Irrelevant? Collateral Attack on Criminal Judgments, 38 U. CH. L. REv. 142 (1970).

145 See Chief Justice Burger, The State of the Judiciary-1970, 54 A.B.A.J. 929 (1970).

146 See cases cited in Note, Interlocutory Appeal from Orders Striking Class Action Allegations, 70 CoLUM. L. REv. 1292 (1970).

147 See, e.g., 3 L. Loss, Securities REgulation 1819 (2d ed. 1961).

148 Ruder, supra note 26. 
than the net worth of the company. ${ }^{149}$ The bankruptcy of a corporation, as a result of high class action damages, is apparently not idle speculation. In Percodani v. Riker-Maxson Corp. ${ }^{150}$ the court ruled that under rule 23(e) a settlement of $\$ 1,800,000$ on an initial claim of $\$ 12,000$, 000 was unfair to the class. The court rejected an argument by defendant corporation that larger damages would result in liquidation of the corporation, and required defendants to provide proof of the corporation's inability to pay more than the settlement price..$^{161}$

These three pressures favoring class actions can be exerted more easily since the 1966 liberalization of rule 23. Actions now maintained on the basis that "common questions" predominate previously were considered "spurious" and did not carry with them the ability to bind, favorably or unfavorably, absent class members. This change, which was considered radical by some, ${ }^{152}$ was not intended to affect substantive law. ${ }^{153}$ Nevertheless, the pressures for class actions, operating through this liberalized mechanism, may explain in part the singular efforts of the courts in $10 \mathrm{~b}-5$ cases to de-emphasize requirements that call for individual fact determinations.

As has been pointed out, a "common questions" determination cannot be divorced from the substantive law elements of a claim, such as reliance. To dismiss a class action for failure to prove reliance would be directly contrary to the pressures upon the court. To have a separate trial on reliance is unrealistic, as the Supreme Court recognized in Mills, since it would result in the very proliferation of judicial work that class actions are supposed to prevent. Likewise, sub-class treatment of members with certain different characteristics is not likely to allow preservation of subjective elements of a claim because the very act of separation into groups requires scrutiny of the individual members of the class. Thus two alternatives exist. One is to minimize or eliminate the element, as the Supreme Court did in Mills. The other is to preserve the element and dismiss the action as Judge Mansfield did in Korn and Judge Pollack did in Morris. The consequence, however, of raising the issue in the procedural context of a rule 23 motion is that the court is not forced to be very frank about change in the substantive law, and change may thus occur without adequate consideration of its desirability. ${ }^{154}$

149 Id. at 429 .

15050 F.R.D. 473 (S.D.N.Y. 1970).

$151 \mathrm{Id}$. at 478.

152 3B Moore's Federal Practice đ 23.45(1), at 23-702 (2d ed. 1969).

153 This was the proviso of the Enabling Act. See note 5 supra.

154 Class actions pose for the courts, through the mechanism of common questions, peculiar strains on judicial decision-making. What a court is doing under the rubric of 
If substantive law is changing as a result of the pressures of conservation of judicial resources, compensation and deterrence, it is important to see how these pressures are being served by the expansion of $10 \mathrm{~b}-5$ liability.

The assertion that class actions conserve judicial resources is open to serious challenge. Class actions are instituted under $10 \mathrm{~b}-5$ in situations where no, or very few, individuals would bother to bring suit. The expectation that class actions would save time was premised on the assumption that many individuals would sue separately. This is somewhat unrealistic, insofar as apathetic individuals with small claims are likely to be unaware of their rights. Indeed, the unlikely incidence of individual actions is used as an argument to support the compensation objective. As the tortuous history of Eisen ${ }^{155}$ indicates, the management problems in class actions can consume a great deal of judicial time.158 Further, the complex nature of the procedural problems can trigger a series of motions and appeals on these issues long before a court reaches the merits.

That class actions will increase compensation is similarly problematic. Consider this startling statement by the premier plaintiffs' class action attorney, Abraham Pomerantz: "Either inertia (especially in our affluent society), or the often difficult task of gathering up proof of claims, tends to make the injured class member unwilling or unable to pick up his share of the recovery effected by the volunteer plaintiff."157 Thus, the same apathy that was apparent to Judge Mansfield in the Korn case reappears with regard to the collection of damages. In securities cases where a plaintiff class is easily identified and transfer records are kept, this problem may be circumvented by mailing a check directly to those who bought or sold between certain dates..$^{158}$ However, where,

common questions is deciding what facts should make a difference. They are presented with multiple plaintiffs with different factual predicates at the same time. They do not have the luxury of the "common law tradition" to take different factual situations in a series of cases. The necessity to deal with these facts simultaneously puts a high premium on judicial competence since the effects of one poorly reasoned decision may be significantly greater than in an individual action. See Justice Black's dissent from the adoption of the change in rule 23, 39 F.R.D. 272, 274 (1966), where he remarked that the change gave rise to a danger of one judge having too much power.

155 See text at notes 125-28 supra.

166 There is nothing new in this observation. See 1 POMEROY, EQUTrY JuRISPRUdence \$ 251 (4th ed. 1918), stating: '[T] interest, or some common question, or else the decree of a court of equity, and the relief given by it in the one judicial proceeding could not by any possibility avail to prevent the multiplicity of suits...."

157 Pomerantz, New Developments in Class Actions-Has Their Death Knell Been Sounded?, 25 Bus. LAw. 1259, 1260 (1970) (emphasis added).

168 This was the procedure adopted on remand in Swanson v. American Consumer 
as in Eisen, a large percentage of stock is held in street name or in trust by a large institution, the problem of identifying persists. Further, as Judge Mansfield indicated in Korn, where a thousand investors were involved, individuals in a mobile society are difficult to trace, even if they can be identified.

Pomerantz suggests an alternative distribution system, based on the doctrine of $c y$ pres, ${ }^{159}$ in which damages would be a form of automatic relief given to that class most similar to the one actually harmed. This form of relief already may occur in a derivative suit where the shareholders have changed by the time the corporation recovers damages. ${ }^{100}$ Conceivably it could be implemented in antitrust cases such as Eisen by lowering the price-differential on odd-lot commissions for a time sufficient to cover the damages. The theory would be that a close identity exists over time between odd-lot purchasers. It is, however, difficult to imagine an equally satisfactory solution in a Texas Gulf Sulphur situation. The closest class to the actual sellers is probably the present shareholders who are, however, indirectly (that is, through the corporation) defendants. The next best class is probably the public at large, which might obtain uncollected damages through escheat. This alternative, however, is far from compensation of the injured class, and may be a better argument for deterrence than for compensation.

Another reason the class may not be well compensated is that attorney's fees often consume a major portion of any damage award.101 These fees are substantial whether the case is settled or is fully litigated. The possibility of large settlements and consequent large attorney's fees is the basis for the contention of corporate defendants and their attorneys, that "strike suits" are common; courts, too, have recognized the danger of strike suits. ${ }^{182}$ The incentive for strike suits under $10 \mathrm{~b}-5$ will no doubt increase with the relaxation of substantive requirements since plaintiff attorneys will have increased leverage in bargaining situations. Although rule 23(e) seeks to prevent such suits through judicial approval and notice to the class of any settlement, ${ }^{163}$ the practical problems of implementing these safeguards have not been

Indus., 415 F.2d 1326 (7th Cir. 1969). The procedure was explained in an interview with plaintiff's attorney, Richard Orlikoff, of Orlikof,, Prins, Flamm \& Susman, Chicago, Illinois, Dec. 30, 1970.

158 Pomerantz, supra note 157, at 1260.

160 Those selling their shares before judgment might also benefit if the market is discounting the value of expected recovery.

161 See Hornstein, Legal Therapeutics: The "Salvage" Factor in Counsel Fee Awards, 69 HARV. L. REv. 658, 662-63 (1956).

162 Cherner v. Transitron Electronic Corp., 201 F. Supp. 934, 936-37 (D. Mass. 1962)

(Wyzanski, J.).

168 FED. R. Crv. P. 23(e). 
resolved. It is unclear, for example, whether a court can compel a named party plaintiff and his attorney to continue an action once they reach an out-of-court settlement, or whether the class interests would be protected if.they were so compelled. ${ }^{164}$

Moreover, compensation for defrauded investors is often paid, indirectly, by innocent shareholders of the defendant corporation. If the corporation is a defendant, or if it indemnifies its executives, ${ }^{165}$ any recovery will decrease the equity of existing shareholders. If compensation is desirable, it is difficult to see why, especially in a large public corporation, it should be achieved at the shareholder's expense. ${ }^{166}$

The limiting case of this anomaly arises when the corporation is liquidated because of a damage award. This may be not only unfair to the shareholders but also extremely uneconomical. Creditors and employees as well as shareholders would be directly affected. Some thought should be given to the "capitalization" of class action damages by a judicially created security interest for plaintiff class in the corporation. This would avoid the harshest feature of class action damages, the lump sum payment. Existing shareholders could reasonably be expected to favor dilution of their interests over bankruptcy.

The final benefit alleged to result from expanded liability under $10 \mathrm{~b}-5$ is deterrence of securities fraud. This is acknowledged to be the principal objective of the Act. ${ }^{167}$ But the crucial question-which has never been addressed empirically-is whether and how well the current state of 10b-5 law serves the deterrence goal.

Given the costs associated with changes in the substantive law evoked by the class action device and the questionable achievement of the other two pressures used to justify these changes, it is imperative that the question of deterrence be examined on a systematic basis. ${ }^{168}$ It could be evaluated from a number of perspectives: through the use of market

164 For a description of the settlement process, see Haudek, The Settlement and Dismissal of Stockholders' Actions, 22 Sw. L.J. 767 (1968), and 23 Sw. L.J. 765 (1969).

165 See Symposium-Insider Indemnification and the Supremacy Clause: The Three Faces of Fraud, 63 Nw. U.L. REv. (1968).

166 See Note, Punitive Damages in Implied Private Actions for Fraud Under the Securities Laws, 55 CORNELL L. REv. 646, 658 (1970), which opposes any imposition of punitive damages for this reason. This consideration should apply equally to "normal" damages if they are substantial. Judge Friendly, concurring, in Texas Gulf Sulphur, 401 F.2d at 867 , has indicated his misgivings about the large damages flowing out of such suits. 107 See Tracy \& MacChesney, supra note 37.

168 Professor Henry G. Manne has already charted the course for future inquiry. See H. MANne, INSIDER TRADING AND THE Stock MARkET (1966), and Insider Trading and the Law Professors, 23 Vand. L. Rev. 547 (1970). See also Economic Policy and the Regulation of Corporate Securities (H. Manne ed. 1969); Schotland, Unsafe at Any Price: A Reply to Manne, Insider Trading and the Stock Market, 53 VA. L. REv. 1425 (1967). 
data before and after disclosures, ${ }^{109}$ through an examination of the Securities and Exchange Commission's ability to detect violations, ${ }^{170}$ through interviews of corporate managers and their counsel to test their knowledge of the potential effects of $10 \mathrm{~b}-5$ violations, ${ }^{171}$ and through an analysis of market institutions which presently facilitate the use of inside information. ${ }^{172}$ Until comprehensive analysis of data along these lines is available, the evolving expansion of liability under $10 \mathrm{~b}-5$ class actions may be both undesirable and unwarranted.

169 See generally Fama, Fisher, Jensen \& Roll, The Adjustment of Stock Prices to New Information, 10 INT'L ECON. REv. 1, 20 (1969) ("instantaneous" absorption of new information by market); Lorie \& Niederhoffer, Predictive and Statistical Properties of Insider Trading, $11 \mathrm{~J}$. LAw \& EcoN. 35, 52 (1968) ("Insiders tend to buy more often than usual before large price increases and sell more often than usual before price decreases.").

170 A former Chairman of the SEC, Milton Cohen, apparently believes that the SEC's deterrence is measurable by the shortage of cases, a rather dubious empirical test. See Cohen, Commentary-Current Problems in Securities Regulation, 19 Catholic U.L. REv. 75,78 (1969) ("Their adherence to the principle [not using inside information] is proven by the relative shortage of cases dealing with violation of disclosure rules.").

171 Many law firms attempt to "school" their clients in the maze of 10b-5. Interview with Leo Herzel of Mayer, Brown \& Platt, Chicago, Illinois, Oct. 30, 1970.

172 Manne has raised questions about whether discretionary accounts might provide an ex-officio information exchange, and whether there may be a conversion of information by mutual fund managers to their own use. Manne, Insider Trading and the Law Professors, supra note 168 , at 584-88. 